uranium could be used. Another development of which the Dragon people are proud is the development of coated particle fuels which retain a large proportion of the fission products. This has made it possible to dispense with or to simplify the arrangements for preventing the escape of fission products into the reactor cooling cycle.

The Dragon programme is at present intended to end in March 1967 and will by then have cost $£ 25$ million. An extension of three years at a cost of $\mathfrak{£} 6$ million is at present being considered. About a third of the total cost has gone on the construction of the reactor experiment, a third on running the reactor, and a third on research and development. Mr. Rennie claims that in its present state of development the high-temperature reactor will need less research and development to bring it to a commercial viable state than will the obvious competitors of this system.

\section{Physics Teaching in Britain}

THe Institute of Physics and the Physical Society has set out to give physics teachers in British schools and technical colleges a greater sense of community with professional physicists. One manifestation of this is the appearance of a new journal Physics Education intended to provide a certain amount of practical help for the classroom teacher but primarily to inform him (or her) of innovations in teaching technique. Pleased though the physicists were last week with their new venture, there were chemists to be heard saying that the new journal follows some years after the appearance of Education in Chemistry, designed to cater for the needs of chemistry teachers in schools and similar institutions.

Prof. K. W. Keohane, professor of physics in the Chelsea College of Advanced Technology and consultative editor of the new journal, says in his introduction that he intends to cater for the interests of teachers of physics "at all levels, from the upper forms in schools to the universities, colleges of education, technical colleges and indeed industry". Prof. Keohane is about to become the coordinator of the Nuffield Foundation Science Teaching Project and he says, in his introduction, that the atmosphere created by curriculum development projects like that of the Physical Sciences Study Committee in the United States and the Nufficld Foundation in Britain have made timely the launching of the new journal. He argues that there will be a need for "regular and continuous servicing" of the new curricula and effort by educational authorities to ensure that teachers are enabled to keep up not only with rapid advances in knowledge but also with developments in the curriculum and teaching method. Universities, the argument goes, should watch out for the influx of students from the schools brought up on a refreshing curriculum.

The new journal is only a part of the plans of the Institute and Society for fostering interest in physics education. A joint committee with the Royal Society, called the Committee on Physics Education, with Sir Nevill Mott as chairman, is plotting other schemes. One of these is an attempt to create regional centres to which physics teachers in schools may look for help, advice and continuing opportunities for training. The first of these centres is likely to emerge around the Department of Physics of the Manchester Institute of Science and Technology.

\section{Nuffield Science Teaching}

The Nuffield Foundation has announced that Prof. Kevin Keohane, head of the Department of Physics at the Chelsea College of Science and Technology, is to become co-ordinator of the Nuffield Foundation Science Teaching Project from August 1, 1966. The work of the Project is at a particularly interesting stage, partly because the developments of the past four years are about to culminate in the publication of the books which embody O-level courses in physics, chemistry and biology, and partly because systematic trials of sixth form and combined science courses are about to begin. Prof. Keohane will combine responsibility for the Science Teaching Project with some of his present duties at Chelsea. From the point of view of the College, the appointment serves to emphasize the interest which has been taken at Chelsea in the past two years in fostering links between academic institutions and the schools. The College has, for example, been concerned to find ways of helping with the training of science teachers and has at various times considered the possibility of starting a unit for this purpose.

\section{Atomic Energy Commission}

The E. O. Lawrence memorial awards of the Atomic Energy Commission have been presented to the following for contributions to nuclear science: Harold M. Agnew, Los Alamos Scientific Laboratory, for development of nuclear weapons; Ernest C. Anderson, also of Los Alamos, for research in nuclear medicine and biology and for development of liquid scintillation counting; John R. Huizenga, Argonne National Laboratory, for work in nuclear fission processes; Murray Gell-Mann, professor of physics at California Institute of Technology, for contributions to the theory of elementary particles; and Paul R. Vanstrum, Oak Ridge Gaseous Diffusion Plant, for technical administration and leadership in developing isotopic separation for uranium.

\section{Canadian Science Council}

THE Canadian Government has established a council to advise on science policy, called the Science Council of Canada, under the chairmanship of Dr. O. M. Solandt, vice-president for research and development of de Havilland Aircraft of Canada, Ltd. Dr. Solandt is well qualified for his new post by his previous experience as the first chairman of the Defence Research Board of Canada, which he helped to plan and which was formed in 1947. Since then, he has been in charge of research and development at the Canadian National Railway, and was elected chancellor of the University of Toronto for two years beginning in July 1965. The vice-chairman of the Science Council of Canada will be Dr. Roger Gaudry, at present rector of the University of Montreal, but with previous industrial experience in pharmaceuticals.

\section{Rockefeller Animal Behaviour}

The Rockefeller. University and the New York Zoological Society have jointly established an Institute for Research in Animal Behavior at New York. The Institute will not be a building but rather a group of scientists attached to one or other of the sponsoring institutions which will collaborate in research and teaching in animal behaviour. One of the facilities available to the new Institute will be the Now York Zoological Society's collection of living animals.

They also plan to make a number of joint appointments to the faculties of the two institutions. Prof. Donald $R$. Griffin has been appointed director of the Institute. $\mathrm{He}$ will be joined later this summer by Prof. Peter Marler, from the University of California at Berkeley, and by Drs. Fernando Nottebohm, Richard Penney and Roger Payne. The Rockefeller University hopes that the work of the new Institute will form part of the overall development of teaching and research in the behavioural sciences which have been organized in recent years by Dr. Carl Pfaffmann, and that this part of the University's interest will be helped by the appointment of Prof. Neal E. Miller, a psychologist, to the faculty.

\section{Effect of Dietary Lipids on Blood}

A symposium was held in Cambridge on March 17 and 18,1966 , under the chairmanship of Prof. A. C. 